\title{
HUBUNGAN NILAI-NILAI PANCASILA TERHADAP PEMBENTUKAN KARAKTER SISWA KELAS VIII DI SMP YAYASAN PENDIDIKAN ESA PRAKARSA TAHUN PELAJARAN 2018/2019
}

\author{
Intan Permata Sari Harahap ${ }^{1}$, Arsip Perangin-Angin ${ }^{2}$, Nurul Hasanah ${ }^{3}$ \\ STKIP BUDIDAYA BINJAI
}

\begin{abstract}
ABSTRAK
Penelitian ini bertujuan untuk mengetahui ada atau tidaknya hubungan nilai pancasila terhadap pembentukan karakter siswa kelas VIII di SMP yayasan pendidikan Esa Prakarsa tahun pelajaran 2018/2019. Penelitian ini adalah penelitian korelasi. Sampel dalam penelitian ini adalah siswa kelas VIII SMP Esa Prakarsa tahun pelajaran 2018/2019 sebanyak 79 siswa. Berdasarkan hasil analisis data diketahui terdapat hubungan yang signifikan antara variabel pemahaman nilai-nilai Pancasila dengan pembentukan karakter siswa SMP Esa Prakarsa. Nilai pearson correlation atau nilai $r$ hitung sebesar 0,642, artinya ada hubungan yang positif dan sangat kuat antara pemahaman nilai-nilai Pancasila dengan pembentukan karakter siswa.
\end{abstract}

Kata kunci: nilai pancasila, karakter

\section{PENDAHULUAN}

Pendidikan adalah usaha sadar dan terencana untuk mewujudkan suasana belajar dan proses pembelajaran agar peserta didik secara aktif mengembangkan potensi dirinya untuk memiliki kekuatan spiritual keagamaan, pengendalian diri, kepribadian, kecerdasan, akhlak mulia, serta keterampilan yang diperlukan dirinya, masyarakat, bangsa dan negara. Dalam Undang-Undang Nomor 20 tahun 2003 tentang pendidikan nasional menyatakan tujuan pendidikan yaitu : Mengembangkan kemampuan dan membentuk watak serta peradaban bangsa yang bermartabat dalam rangka mencerdaskan kehidupan bangsa, bertujuan untuk berkembangnya potensi peserta didik agar menjadi manusia yang beriman dan bertakwa kepada Tuhan Yang Maha Esa, berakhlak mulia, sehat, berilmu cakap, kreatif, mandiri dan menjadi warga negara yang demokratis serta bertanggung jawab.

Pada saat ini pendidikan menjadi perhatian yang sangat serius dalam masyarakat. Anak semakin pintar dan terdidik dengan baik dalam segi ilmu pengetahuannya (intelektual). Namun dalam segi moral maupun karakter sangat memperihatinkan. Karakter anak semakin mengalami kemunduran yang sangat drastis. Anak cenderung melanggar norma-norma yang ada di Indonesia dengan sangat mudahnya dan tak merasakan rasa bersalah. Padahal mereka telah mengetahui akibat yang akan diterima apabila melanggar norma-norma tersebut. Anak melanggar norma-norma tersebut dikarenakan kurangnya perhatian dari orang tua mereka. Menurut Thomas Lickona : Perhatian dan peranan orang tua dalam perkembangan anak sangatlah penting karena orang tua adalah guru moral pertama anak-anak, pemberi pengaruh yang paling dapat bertahan lama, anakanak berganti guru setiap tahunnya, tetapi mereka memiliki satu orang tua sepanjang masa pertumbuhan. Hubungan orang tua anak juga mengandung signitifikansi emosional khusus, yang bisa menyebabkan anak-anak merasa dicintai dan berharga atau sebaliknya merasa tidak dicintai dan tidak berharga. Terakhir, orang tua berada pada posisi sebagai pengajar moralitas yang merupakan bagian dari pandangan dunia yang lebih luas yang menawarkan sebuah visi kehidupan dan alasan utama untuk menjalani kehidupan yang bermoral. 
Namun dalam realita yang ada, orang tua sibuk dalam berkerja sehingga anak kurang mendapat perhatian dari orang tua. Waktu orang tua untuk anak tidak ada, orang tua sibuk dengan kegiatannya masing-masing. Hal ini mengakibatkan tidak adanya pembentukan moral bagi anak. Anak pun merasa bahwa dirinya tak berharga dan disayangi oleh orang tuanya. Sehingga anak melanggar norma-norma yang ada dan kehilangan akan jati diri atau karakternya. Padahal karater anak sangatlah penting karena anak merupakan penerus bangsa. Jika karakter anak tidak baik maka negara ini akan mengalami kemunduran yang drastis.

Menurut Scerenko karakter adalah atribut atau ciri-ciri yang membentuk dan membedakan ciri pribadi, ciri etis, dan kompleksitas mental dari seseorang, suatu kelompok atau bangsa. Karakter sangat penting dalam suatu bangsa, karena karakter merupakan jati diri dari suatu bangsa. Jika bangsa tidak memiliki karakter maka bangsa akan mengalami kemerosotan yang sangat drastis. Masalah seputar karakter atau moral yang terjadi sekarang ini, jauh lebih banyak dan kompleks dibandingkan dengan masalah-masalah karakter atau moral yang terjadi pada masa-masa sebelumnya. Persoalan karakter menjadi bahan pemikiran sekaligus keprihatinan bersama karena negara ini bisa dianggap sedang mengalami krisis karakter. Krisis ini antara lain ditandai dengan meningkatnya pergaulan bebas, penyalahgunaan obat-obatan, maraknya kekerasaan anak-anak dan remaja, tawuran antarkampung dan sekolah. Permasalahan karakter ini sangat memperihatinkan. Saat ini, kita telah memasuki zaman yang modern atau era globalisasi. Zaman semakin lama mengalami perkembangan dan kemajuan, seharusnya karakter anak bangsa juga harus mengalami peningkatan bukan malah sebaliknya.

Adanya era globalisasi dapat berpengaruh terhadap nilai-nilai budaya bangsa Indonesia. Era globalisasi tersebut telah datang dan menggeser nilai-nilai yang telah ada. Nilai-nilai tersebut bersifat positif dan negatif. Ini semua merupakan ancaman, tantangan, dan sekaligus sebagai peluang bagi bangsa Indonesia untuk berkreasi dan berinovasi di segala aspek kehidupan. Di era globalisasi, pergaulan antarbangsa semakin ketat. Batas antarnegara hampir tidak ada artinya. Batas wilayah tidak lagi menjadi penghalang. Di dalam pergaulan antarbangsa yang semakin kental itu akan terjadi proses alkulturasi, saling meniru dan melunturkan tata nilai yang merupakan jati diri bangsa Indonesia. Globalisasi telah membawa perubahan terhadap pola pikir dan bertindak masyarakat dan bangsa Indonesia, terutama kalangan generasi muda yang cenderung mudah terpengaruh oleh nilai-nilai dan budaya luar yang tidak sesuai dengan kepribadian dan karakter bangsa Indonesia.

Ancaman yang muncul akibat dampak negatif globalisasi tidak dapat dianggap hal kecil. Akibat dari globalisasi ini secara tidak sadar telah berdampak pada karakter bangsa Indonesia yang mulai luntur dan tidak sesuai lagi dengan bangsa ini. Nilai-nilai luhur yang telah ada makin terkikis.

Kondisi ini akhirnya menyebabkan banyak pihak menyimpulkan perlunya landasan dalam membangun karakter sehingga masyarakat memiliki pedoman dalam bersikap dan berperilaku dalam kehidupan berbangsa dan bernegara. Sebagai dasar negara dan ideologi bangsa, pancasila sangatlah tepat jika dijadikan landasan dalam bersikap dan berperilaku karena dalam pancasila terdapat nilai ketuhanan, nilai kemanusiaan, dan nilai persatuan, nilai kerakyatan, dan nilai keadilan. Nilai- nilai pancasila merupakan sebuah norma untuk menata kehidupan manusia. Pentingnya nilainilai yang terkandung pada setiap sila pancasila sebagai wujud dari karakter bangsa Indonesia itu sendiri yang merupakan cerminan sebagai warga negara yang baik (Good Citizen). Pancasila sebagai contoh untuk menjadikan upaya pembangunan karakter bangsa di masyarakat, karena apabila nilainilai pancasila tidak dilaksanakan maka akan terjadi dampak negatif.

Pancasila sebagai kristalisasi nilai-nilai kehidupan masyarakat yang bersumber dari budaya Indonesia telah menjadi ideologi dan pandangan hidup. Pancasila sebagaimana tercantum dalam Pembukaan Undang-Undang Dasar 1945 merupakan ideologi negara dan sebagai dasar negara. Pancasila sebagai pandangan hidup mengandung makna bahwa hakikat hidup bermasyarakat, berbangsa, dan bernegara dijiwa oleh moral dan etika yang dimanifestasikan dalam sikap perilaku dan kepribadian manusia Indonesia yang proposional baik dalam hubungan manusia dengan Maha Pencipta, dan hubungan antara manusia dengan manusia, serta hubungan antara manusia dengan lingkungan.

Pancasila juga sebagai sumber karakter bangsa, maksudnya adalah keseluruhan sifat yang mencakup perilaku, kebiasaan, kesukaan, kemampuan, bakat, potensi, nilai-nilai, dan pola pikir yang dimiliki oleh sekelompok manusia yang mau bersatu, memiliki kesamaan nasib, asal keturunan, bahasa, adat dan sejarah Indonesia. 
Berdasarkan latar belakang masalah diatas, maka penulis tertarik untuk mengadakan penelitian dengan judul "Hubungan Nilai-Nilai Pancasila Terhadap Pembentukan Karakter Siswa kelas VIII Di SMP Yayasan Pendidikan Esa Prakarsa Tahun Pelajaran 2018/2019"

\section{METODOLOGI PENELITIAN}

\section{A. Lokasi dan Waktu Penelitian}

Penelitian ini dilaksanakan di SMP Yayasan Pendidikan Esa Prakarsa Kecamatan Selesai Kabupaten Langkat.

Penelitian ini dilaksanakan di SMP Yayasan Pendidikan Esa Prakarsa. Penelitian dilaksanakan dari bulan April sampai dengan selesai. Untuk lebih jelasnya kegiatan penelitian ini dapat dilihat pada tabel kegiatan pelaksanaan penelitian.

Tabel3.1.

Perenc anaan dan Pelaksanaan Penelitian

\begin{tabular}{|l|c|c|c|c|c|c|}
\hline \multirow{2}{*}{ Kegiatan } & \multicolumn{5}{c|}{ Bulan } \\
\cline { 2 - 7 } & Apr & Mei & Jun & Jul & Agu & Sep \\
\hline Observasi & v & & & & & \\
\hline Pengajuan Judul & v & & & & & \\
\hline Bimbingan Proposal & & & v & & & \\
\hline Seminar Proposal & & & & & v & \\
\hline Bimbingan Skripsi & & & & & v & \\
\hline Pengambilan Data & & & & & v & \\
\hline Sidang & & & & & & v \\
\hline
\end{tabular}

\section{B. Jenis Penelitian}

Penelitian ini menggunakan jenis penelitian korelasi merupakan penelitian yang melihat ada tidaknya hubungan dari kedua variabel.

\section{Populasi dan Sampel Penelitian}

Populasi pada penelitian ini adalah seluruh siswa kelas VIII SMP Yayasan Pendidikan Esa Prakarsa Tahun 2017/2018 yang terdiri dari 3 kelas yang berjumlah 79 siswa.

Tabel 3.2 Populasi

\begin{tabular}{ccc}
\hline No & Kelas & Jumlah \\
\hline 1 & VIII-1 & 25 siswa \\
\hline 2 & VIII-2 & 26 siswa \\
\hline 3 & VIII-3 & 28 siswa \\
\hline & Total & 79 siswa \\
\hline
\end{tabular}

Sampel adalah himpunan bagian atau sebagian dari populasi. Teknik pengambilan sampel menurut teori Suharsimi Arikunto yaitu, apabila subjeknya kurang dari 100, lebih baik diambil semuanya sehingga penelitiannya merupakan penelitian populasi. Tetapi, jika subjeknya besar, dapat diambil 10-15\%, 20-25\% < atau pun lebih.

Berdasarkan teori diatas, karena jumlah populasi kurang dari 100 siswa maka sampel dalam penelitian ini adalah semua siswa VIII SMP Yayasan Pendidikan Esa Prakarsa berjumlah 79 siswa.

Tabel 3.3 Rincian Sampel

\begin{tabular}{ccc}
\hline No & Kelas & Jumlah \\
\hline 1 & VIII-1 & 25 siswa \\
\hline 2 & VIII-2 & 26 siswa \\
\hline 3 & VIII-3 & 28 siswa \\
\hline & Total & 79 siswa \\
\hline
\end{tabular}

\section{Variabel Penelitian}

Variabel adalah semua ciri atau faktor yang dapat menunjukkan variasi. variabel dapat digolongkan menjadi dua macam yaitu sebagai berikut :

1. Variabel Bebas

Variabel Bebas (independent variable) adalah faktor yang menjadi pokok permasalahan yang ingin diteliti. Variabel ini memberi perlakuan atau memberikan pengaruh. Variabel bebas dalam penelitian ini yaitu nilai-nilai pancasila, dengan kode $(\mathrm{X})$.

2. Variabel Kendali atau Variabel Kontrol Variabel Kendali atau Variabel Kontrol adalah variabel yang dikendalikan atau dikontrol, dibuat sama antara kelompok yang diteliti. Variabel ini disebut juga variabel terikat yaitu menerima akibat dari perlakuan atau yang dipengaruhi. Variabel terikat dalam penelitian ini yaitu karakter, dengan kode (Y).

\section{E. Instumen Penelitian}

Untuk memperoleh data yang diperlukan dalam penelitian ini, penulis mempergunakan alat pengumpulan data yang disebut instrumen penelitian. Instrumen penelitian yang digunakan dalam pengumpulan data ini adalah angket dan tes yang diberikan kepada siswa.

\section{Tes}

Menurut Suharsimi Arikunto tes adalah serentetan pertanyaan atau latihan serta alat lain yang digunakan untuk menukur keterampilan, pengetahuan 
intelegensi, kemampuan atau bakat yang dimiliki oleh individu atau kelompok.

Tabel 3.4

Kisi-Kisi Soal Tes
Pemahaman Nilai-Nilai Pancasila

\begin{tabular}{|c|l|c|c|}
\hline Variabel & \multicolumn{1}{|c|}{ Indikator } & No Item & Jumlah \\
\hline $\begin{array}{c}\text { Nilai } \\
\text { Pancasila } \\
(\mathrm{X})\end{array}$ & Nilai sila pertama & $1,2,3,4,5$ & 5 \\
\cline { 2 - 4 } & Nilai sila ke dua & $6,7,8,9,10$ & 5 \\
\cline { 2 - 4 } & Nilai sila ke tiga & $11,12,13,14,15$ & 5 \\
\cline { 2 - 4 } & Nilai sila ke empat & $16,17,18,19,20$ & 5 \\
\cline { 2 - 4 } & Nilai sila ke lima & $21,22,23,24,25$ & 5 \\
\cline { 2 - 4 } & & Total & 25 \\
\hline
\end{tabular}

\section{Angket}

Menurut Suharsimi Arikunto angket atau kuesioner adalah sejumlah pertanyaan tertulis yang digunakan untuk memperoleh informasi dari responden dalam arti laporan tentang pribadinya, atau hal-hal yang ia ketahui.

Jenis angket yang digunakan adalah jenis tertutup yaitu angket yang sudah disediakan jawabannya sehingga responden tinggal memilih. Tujuannya untuk mengetahui informasi lengkap mengenai masalah maupun informasi dari responden.

Sugiono menyatakan disarankan empirik jumlah pertanyaan yang memadai adalah antara 20 s/d 30 pertanyaan. Oleh sebab itu, penulis membuat angket dalam penelitian ini sebanyak 25 item pertanyaan. Skala likert digunakan untuk mengukur sikap,pendapat, dan peresepsi seseorang atau sekelompok orang tentang fenomenal sosial. Dalam penelitian, fenomenal sosial ini telah ditetapkan spesifik olehpeneliti, yang selanjutnya disebut sebagai variabel penelitian. Instrumen ini menggunakan skala likert,yang memiliki jawaban dengan gradasi dari Selalu (SL), Sering (SR), Kadang-kadang (KD), dan Tidak Pernah (TP). Tipe jawaban yang digunakan adalah berbentuk silang (X). Skor setiap alternatif jawaban yang diberikan oleh responden pada pernyataan adalah sebagai berikut :

Tabel 3.5 Skor Alternatif Jawaban Angket

\section{Pernyataan}

\begin{tabular}{lc}
\hline \multicolumn{1}{c}{ Alternatif Jawaban } & Skor \\
\hline Selalu (SL) & 4 \\
\hline Sering (SR) & 3 \\
\hline Kadang-kadang (KD) & 2 \\
\hline Tidak Pernah (TP) & 1 \\
\hline
\end{tabular}

F. Teknik Analisis Data

Korelasi product moment adalah salah satu teknik untuk mencari korelasi antara dua variabel yang kerap kali di gunakan. Korelasi product Moment (KPM) atau sering juga disebut korelasi pearson merupakan alat uji statistik yang digunakan untuk menguji hipotesis asosiatif (uji hubungan) dua variabel bila datanya berskala interval atau rasio. Untuk menghitung nilai korelasi product moment dalam penelitian ini digunakan software SPSS. 16.

Berdasarkan alat pengumpulan data yang digunakan maka setelah data terkumpul dilakukan pengorganisasian dengan tahap sebagai berikut:

1. Data yang terkumpul dipilih berdasarkan klasifikasinya

2. Memberi skor jawaban tes dan angket tiap pertanyaan

3. Mengitung jumlah skor tiap responden

4. Mengklasifikasi skor tiap responden

Untuk menganalisa data yang telah di kumpulkan penulis gunakan analisa statistik dengan rumus korelasi product moment person yaitu:

$$
\mathrm{r}_{\mathrm{xy}}=\frac{n \sum X Y-\left(\sum X\right)\left(\sum Y\right)}{\mathrm{v}\left[n \sum X^{2}-\left(\sum X\right)^{2}\right\}\left\{n \mathrm{n}^{2}-\mathrm{Y}^{2}-(\mathrm{Y})^{2}\right\}}
$$

Keterangan :

$\begin{array}{ll}\mathrm{r}_{\mathrm{xy}} & \begin{array}{l}\text { : angka indeks " } \mathrm{r} \text { " produk moment } \\ \text { (antara variabel } \mathrm{X} \text { dan } \mathrm{Y})\end{array} \\ \mathrm{N} & \text { : Jumlah responden } \\ \mathrm{XY} & \text { : Jumlah hasil perkalian antara skor } \mathrm{X} \\ & \quad \text { dan } \mathrm{Y} \\ \mathrm{X} & \text { : Jumlah seluruh skor } \mathrm{X} \\ \mathrm{Y} & \text { : Jumlah seluruh skor } \mathrm{Y}\end{array}$

\section{HASIL PENELITIAN DAN PEMBAHASAN}

\section{A. Deskripsi Lokasi, Sampel dan Waktu Penelitian}

\section{Lokasi Penelitian}

Lokasi yayasan pendidikan SMP Esa Prakarsa dapat dikatakan sangat strategis, karena terletak di tepi jalan raya Binjai-Kuala dengan alamat kelurahan Pekan Selesai, Kec. Selesai, Kab. Langkat, Prov. Sumatera Utara. Di sekitar SMP Esa Prakarsa terdapat rumah-rumah penduduk yang cukup padat. Lokasinya pun mudah dijangkau karena terdapat kendaraan umum. SMP Esa Prakarsa merupakan sekolah yang asri dan terjaga kebersihannya. Keadaan lingkungan sekolah cukup tenang dan tidak terlalu bising walaupun dekat jalan utama Binjai-Kuala sebab tata bangunan sekolahan menjorok menjauhi jalan raya dan letaknya agak menjauh dari kebisingan kota serta berpagar keliling. Sehingga proses pembelajaran dapat berjalan dengan efektif. Berikut ini adalah basic data SMP Esa Prakarsa yang peneliti dapatkan dari kepala sekolah SMP Esa Prakarsa bapak Serasi Bagun, S.Pd. 
1. NPSN : 10201040

2. Status : Swasta

3. Bentuk Pendidikan : SMP

4. Status Kepemilikan : Yayasan

5. SK Pendirian Sekolah : 01/YS.EP-SEL/1998

6. Tanggal SK Pendirian : 1998-08-20

7. SK Izin Operasional : NO.421.2/078/I/2016

8. Tanggal SK Izin Operasional : 2010-03-06

SMP Esa Prakarsa dalam menjalankan proses pendidikannya selalu mengedepankan visi dan misi yang telah ditetapkan oleh pihak sekolah. Berikut adalah visi dan misi SMP Esa Prakarasa.

VISI :

"Membentuk Siswa-Siswi Yang Berdisiplin, Bermoral, Dan Berkualitas"

MISI :

1. Melengkapi sarana dan prasarana secara baik sehingga tercipta susasana belajar yang aman, nyaman dan hormonis.

2. Melaksanakan pembelajaran dan bimbingan secara efektif.

3. Menumbuhkan penghayatan terhadap ajaran agama.

4. Melaksanakan pembelejaran dengan menggunakan media elektronik.

Agar visi dan misi yang diharapkan dapat terwujud, SMP Esa Prakarsa memfokuskan proses pembelajaran untuk senantiasa memberikan informasi dan pendidikan terbaik bagi para siswa. Dalam menjalankan pendidikannya, SMP Esa Prakarsa berusaha untuk selalu menjalankan tanggung jawab kepada masyarakat dan menciptakan manfaat.

\section{Sampel Penelitian}

Sampel penelitian dalam penelitian ini merupakan seluruh siswa kelas VIII SMP Esa Prakarsa tahun pelajaran 2018/2019 yang berjumlah berjumlah 79 siswa yang berasal dari tiga kelas. Dikarenakan jumlah seluruh siswa kelas VIII SMP Esa Prakarsa kurang dari 100 siswa maka penentuan subjek penelitian adalah didasarkan atau diperoleh dengan cara mengambil sampel menurut teori Suharsimi Arikunto yaitu, apabila subjeknya kurang dari 100 , lebih baik diambil semuanya 10 $15 \%, 20-25 \%<$ atau pun lebih. Berikut ini adalah rincian sampel penelitian yang didapat:

Tabel 4.1 Sampel Penelitian

\begin{tabular}{ccc}
\hline No & Kelas & Jumlah \\
\hline 1 & VIII-1 & 25 siswa \\
\hline 2 & VIII-2 & 26 siswa \\
\hline 3 & VIII-3 & 28 siswa \\
\hline
\end{tabular}

Total

79 siswa

\section{Waktu Penelitian}

Penelitian ini dilakukan pada minggu terakhir bulan Agustus 2018, waktu tersebut telah dimaksimalkan untuk pengambilan data melalui soal tes nilai-nilai Pancasila dan angket. Selain pengambilan data melalui tes dan angket peneliti mengambil data dokumen-dokumen yang berkaitan dengan kebutuhan penelitian. Peneliti juga melakukan kegiatan kunjungan di SMP Esa Prakarsa pada bulan Mei 2018 untuk meminta ijin akan melaksanakan penelitian di SMP Esa Prakarsa. Sehingga peneliti sudah mengetahui sedikit kondisi di SMP Esa Prakarsa. Oleh karena itu pada akhir Agustus 2018 langsung dilakukan pengambilan data selama 2 hari. Tabel 4.2 berikut ini adalah waktu pengambilan data.

Tabel 4.2 Waktu Pengambilan Data

\begin{tabular}{cll}
\hline No & Hari/Tanggal & \multicolumn{1}{c}{ Kegiatan } \\
\hline 1 & Sabtu / 25-08- & Pengambilan data kelas \\
& 2018 & VIII-1 dan VIII-2 \\
\hline 2 & Senin / 27-08- & Pengambilan data kelas \\
& 2018 & VIII-3 \\
\hline
\end{tabular}

\section{B. Deskripsi Hasil Penelitian}

1. Deskripsi Nilai-Nilai Pancasila dan Karakter Siswa

Dari hasil penelitian yang telah dilakukan, maka diperoleh hasil penelitian nilai-nilai Pancasila dan karakter siswa yang telah diolah sescara statistik sebagai berikut:

Tabel 4.3

Descriptive Statistics

\begin{tabular}{|l|r|r|r|r|r|}
\hline & N & Minimum & Maximum & Mean & Std. Deviation \\
\hline Nilai Pancasila & 79 & 51 & 89 & 70.19 & 10.462 \\
Karakter Siswa & 79 & 57 & 85 & 70.76 & 7.231 \\
Valid N (listwise) & 79 & & & & \\
\hline
\end{tabular}

Melihat data yang diperoleh tersebut maka dapat disimpulkan bahwa mayoritas dari siswa kelas SMP Esa Prakarsa mempunyai pemahaman nilai-nilai Pancasila yang baik. Tentu ini merupakan hal yang positif, karena dengan pemahaman nilai-nilai Pancasila yang baik maka siswa diharapkan bisa mengamalkannya dalam kehidupan sehari-hari. Namun yang perlu diingat masih ada beberapa siswa yang mempunyai pemahaman terhadap nilai-nilai Pancasila dengan tingkat pemahaman yang sedang. Tentu hal ini harus segera ditangani, karena sebagai warga negara Indonesia sudah seharusnya mempunyai 
pemahaman terhadap nilai-nilai yang terkandung dalam dasar negera tersebut.

Merujuk pada tabel 4.1di atas maka dapat disimpulkan bahwa mayoritas karakter dari siswa kelas VIII SMP Esa Prakarsa tergolong baik. Tentu ini merupakan hal yang positif karena karakter yang baik akan berdampak pada sikap dan perilaku siswa tersebut. Namun yang perlu menjadi perhatian bahwa masih ada siswa yang mempunyai karakter sedang dan mempunyai karakter rendah. Tentu hal ini merupakan permasalahan tersendiri, karena karakter akan nampak pada sikap dan perilaku seseorang tersebut, sehingga apabila mempunyai karakter yang belum baik maka sikap dan perilakunya juga belum baik. Oleh karena itu hal ini harus segera ditangani, karena beberapa siswa yang mempunyai karakter yang belum ideal tersebut bisa membawa damapak yang negatif bagi siswa lainnya.

\section{Uji Hipotesis}

Analisis bivariat dilakukan untuk melihat hubungan antara variabel pemahaman nilai-nilai Pancasila dengan pembentukan karakter siswa kelas VIII SMP Esa Prakarsa. Dengan adanya uji hipotesis ini maka akan terlihat apakah terdapat hubungan atau tidak antara pemahaman nilai-nilai Pancasila siswa kelas VIII SMP Esa Prakarsa dengan karakter 79 siswa kelas VIII SMP Esa Prakarsa. Uji hipotesis yang digunakan dalam penelitian ini adalah analisis bivariat dengan teknik korelasi menggunakan Korelasi Product Moment dan dengan tingkat kemaknaan $(\alpha=0,05)$. Hasil dari uji tersebut adalah sebagai berikut:

Tabel 4.4

\begin{tabular}{|c|c|c|c|}
\hline \multicolumn{4}{|c|}{ Correlations } \\
\hline & & Nilai Pancasila & Karakter Siswa \\
\hline \multirow[t]{3}{*}{$\begin{array}{l}\text { Nilai } \\
\text { Pancasila }\end{array}$} & $\begin{array}{l}\text { Pearson } \\
\text { Correlation }\end{array}$ & 1 & $.642^{-1}$ \\
\hline & Sig. (2-tailed) & & .000 \\
\hline & $\mathrm{N}$ & 79 & 79 \\
\hline \multirow[t]{3}{*}{$\begin{array}{l}\text { Karakter } \\
\text { Siswa }\end{array}$} & $\begin{array}{l}\text { Pearson } \\
\text { Correlation }\end{array}$ & $.642^{-4}$ & 1 \\
\hline & Sig. (2-tailed) & .000 & \\
\hline & $\mathrm{N}$ & 79 & 79 \\
\hline
\end{tabular}

Berdasarkan hasil perhitungan diperoleh nilai pearson correlation atau nilai $r$ hitung sebesar 0,642 dan sig. atau probabilitas sebesar 0,000 $(0,000<0,05)$, maka Ha diterima (hipotesa diterima). Hal ini menunjukkan bahwa terdapat hubungan yang signifikan antara variabel pemahaman nilai-nilai Pancasila dengan pembentukan karakter siswa SMP Esa Prakarsa. Nilai nilai pearson correlation atau nilai $r$ hitung sebesar 0,642 , artinya ada hubungan yang positif atau erat antara pemahaman nilai-nilai Pancasila dengan karakter siswa. Dengan demikian semakin tinggi pemahaman nilai-nilai Pancasila maka pembentukan karakter siswa semakin baik, atau semakin rendah pemahaman nilai-nilai pancasila maka karakter siswa semakin buruk.

\section{Pembahasan}

Hasil analisis uji korelasi product moment pada penelitian ini menunjukkan bahwa terdapat hubungan yang positif antara pemahaman nilai-nilai Pancasila dengan karakter siswa. Hal ini menunjukkan bahwa terdapat hubungan sebab akibat dimana pemahaman nilai-nilai pancasila memberikan akibat atau dampak positif terhadap karakter siswa. Semakin tinggi pemahaman nilainilai pancasila maka karakter siswa semakin baik, atau semakin rendah pemahaman nilai-nilai pancasila maka karakter siswa semakin buruk. Hal ini ditunjukkan oleh nilai sig. sebesar 0,000 lebih kecil dari 0,05. Besarnya hubungan antara pemahaman nilai-nilai pancasila dengan karakter siswa adalah sebesar 0,642 atau sebesar 64,2\%, dimana hubungan kedua variabel cukup kuat atau tinggi.

Berdasarkan uji korelasi antara variabel pemahaman nilai-nilai Pancasila dengan variabel karakter siswa kelas VIII SMP Esa Prakarsa, menunjukkan bahwa terdapat hubungan yang signifikan. Dalam uji korelasi tersebut terlihat bahwa tingkat pemahaman nilai-nilai Pancasila siswa mempengaruhi karakter yang dimiliki oleh siswa. Oleh karena itu pemahaman nilai-nilai Pancasila merupakan sesuatu yang sangat penting diajarkan kepada siswa karena hal tersebut mempunyai pengaruh terhadap karakter yang dimiliki oleh siswa tersebut. Karena karakter tersebut berkontribusi besar dalam mewujudkan sepenuhnya potensi dan cita-cita seseorang dalam membangun kehidupan yang baik, yang bermanfaat bagi dirinya, orang lain, dan bangsanya. Sehingga untuk membentuk karakter siswa maka dapat dilakukan dengan penanaman nilai-nilai Pancasila terhadap siswa. Dengan penanaman nilai-nilai Pancasila yang baik maka diharapkan hal tersebut akan meningkatkan pemahaman siswa terhadap nilai-nilai Pancasila. Sehingga nantinya mempunyai fondasi nilai yang dapat dijadikan dasar untuk pembentukan karakter.

Pancasila yang berisi seperangkat nilai-nilai dasar ideal, merupakan komitmen kebangsaan, identitas bangsa dan menjadi dasar pembangunan karakter. Pancasila sebagai nilai mengandung serangkaian nilai, yaitu: ketuhanan, kemanusiaan, 
persatuan, kerakyatan, keadilan. Kelima nilai ini merupakan satu kesatuan yang utuh, tak terpisahkan mengacu kepada tujuan yang satu. Pancasila sebagai suatu sistem nilai termasuk kedalam nilai moral (nilai kebaikan) dan merupakan nilai-nilai dasar yang bersifat abstrak. Pancasila yang merupakan dasar negara Indonesia mempunyai nilai-nilai karakter yang lengkap dan sangat relevan untuk dijadikan pedoman dalam pembentukan karakter.

Pemahaman nilai-nilai Pancasila mempunyai pengaruh terhadap karakter yang dimiliki oleh siswa. Oleh karena itu pemahaman nilai-nilai Pancasila harus ditingkatkan. Dengan adanya upaya untuk meningkatkan pemahaman nilai-nilai Pancasila siswa maka hal tersebut akan berdampak terhadap karakter yang dihasilkan nantinya. Materi tentang Pancasila yang diajarkan di kelas VIII pada awal semester satu, merupakan salah satu jalan untuk meningkatkan pemahaman siswa terhadap nilai-nilai Pancasila. Dengan pemahaman nilai-nilai Pancasila yang baik maka hal tersebut akan menjadi modal berharga bagi siswa untuk membentuk karakter mereka. Penanaman nilai-nilai Pancasila kepada siswa merupakan upaya untuk meningkatkan pemahaman siswa terhadap nilainilai Pancasila. Nilai-nilai yang terkandung dalam Pancasila apabila diimplementasikan secara benar maka akan berdampak positif terhadap karakter yang dimiliki siswa. Namun sebelum mengimplementasikan nilai-nilai Pancasila tentu siswa harus paham terlebih dahulu terhadap nilainilai Pancasila sebagai modal awal untuk membentuk karakter mereka.

Peningkatan pemahaman nilai-nilai Pancasila harus mendapat perhatian khusus dari pihak sekolah. Melalui kegiatan-kegiatan seperti pramuka maupun kegiatan ekstrakurikuler lainnya bisa dijadikan alternatif sebagai sarana dalam peningkatan pemahaman nilai-nilai Pancasila. Karakter yang baik merupakan sesuatu yang wajib dimiliki oleh siswa, karena karakter akan menentukan perilaku yang ditampilkan oleh siswa tersebut. Sebagai generasi penerus bangsa dimasa depan tentu siswa harus mempunyai karakter yang baik sebagai bekal membangun kehidupan berbangsa dan bernegara. Karena sebenarnya karakter itu bisa dibentuk dan dikembangkan. Salah satunya melalui jalur pendidikan. Oleh karena itu Pendidikan Kewarganegaraan memegang peranan untuk membentuk karakter siswa, yakni karakter yang sesuai dengan nilai-nilai Pancasila.

Pendidikan kewarganegaraan merupakan salah satu mata pelajaran yang bertujuan untuk pembentukan warga negara yang memahami dan mampu melaksanakan hak-hak dan kewajibannya untuk menjadi warga negara Indonesia yang cerdas, terampil dan berkarakter yang diamanatkan oleh Pancasila dan UUD 1945. Selain itu Pendidikan Kewarganegaraan merupakan mata pelajaran yang mengkaji dasar negara kita yakni Pancasila. Oleh karena itu penanaman nilai-nilai Pancasila dapat dilakukan melalui Pendidikan Kewarganegaraan, baik melalui materi yang terdapat dalam Pendidikan Kewarganegaraan maupun mengintegrasikan nilai-nilai Pancasila dalam setiap pembelajaran. Sebenarnya pengintegrasian nilainilai Pancasila tidak hanya bisa dilaksanakan pada pembelajaran Pendidikan Kewarganegaraan, namun bisa juga diintegrasikan dalam setiap mata pelajaran. Karena nilai-nilai yang terkandung dalam Pancasila merupakan nilai-nilai kebaikan yang sangat relevan untuk diintegrasikan dalam setiap mata pelajaran. Nilai-nilai yang terkandung dalam Pancasila mempunyai unsur-unsur yang lengkap dalam membangun sebuah bangsa kuat. Dari lima sila yang terdapat dalam Pancasila mempunyai nilai sendiri-sendiri yang satu sama lain mempunyai hubungan yang bersinergi dalam membangun bangsa ini. Hal itu yang melatarbelakangi Pancasila dijadikan acuan dalam pendidikan karakter, namun juga didukung oleh unsur-unsur lainnya.

Setiap orang diharapkan mempunyai karakter yang baik. Dengan mempunyai karakter yang baik maka orang tersebut akan mempunyai perilaku yang baik. Melalui materi Pancasila dalam pembelajaran Pendidikan kewarganegaraan maka hal ini akan meningkatkan pemahamaan nilai-nilai Pancasila siswa. Dengan pemahaman nilai-nilai Pancasila yang baik maka siswa diharapkan akan mempunyai karakter yang baik juga dan sesuai dengan karakter Pancasila. Oleh karena itu pemahaman nilai-nilai Pancasila sangat penting karena akan berpengaruh terhadap karakter yang dimiliki oleh siswa. Pendidikan karakter merupakan upaya-upaya yang dirancang dan dilaksanakan secara sistematis untuk membantu peserta didik memahami nilai-nilai perilaku manusia yang berhubungan dengan Tuhan Yang Maha Esa, diri sendiri, sesama manusia, lingkungan, dan kebangsaan yang terwujud dalam pikiran, sikap, perasaan, perkataan, dan perbuatan berdasarkan norma-norma agama, hukum, tata krama, budaya, dan adat istiadat.

\section{KESIMPULAN}

Berdasarkan hasil analisis data, deskripsi, dan pembahasan, dapat diambil kesimpulan bahwa terdapat hubungan yang sangat signifikan antara variabel pemahaman nilai-nilai pancasila dengan 
pembentukan karakter siswa SMP Esa Prakarsa. Nilai pearson correlation atau nilai $r$ hitung sebesar 0,642, dengan nilai signifikansi sebesar 0,000 lebih kecil dari 0,05 artinya ada hubungan yang positif antara pemahaman nilai-nilai pancasila dengan karakter siswa.

\section{DAFTAR PUSTAKA}

Alhaj, Pangeran dan Patria, Usmani Surya.2000 Pendidikan Pancasila Universitas Terbuka. Depdiknas. Jakarta

Aprilliyani, 2016. Hubugan Pemahaman NilaiNilai Pancasila Pada Mata Pelajaran Pkn Dengan Karakter Siswa Kelas VI di SD Dharmakarya Pondok Cabe Pamulang

Arikunto,Suharsimi, 2006. Prosedur Penelitian Sua tu Pendekatan Praktik. Rineka Cipta. Jakarta

Asmaroini, Ambiro Puji. 2016. Implementasi Nilainilai Pancasila Bagi Siswa di Era Globalisasi

Asrori, Mohammad. 2017. Psikologi Pembelajaran. CV Wacana Prima. Bandung

Damanhuri, dkk. 2016. Implementasi Nilai-Nilai Pancasila Sebagai Upaya Pembangunan Karakter Bangsa. Serang

Herdiawanto, Heri dan Hamdayama, Jumanta. 2010. Cerdas, Kritis, dan Aktif Berwarganegara. Erlangga. Jakarta

Jalaluddin dan Abdullah. 2017. Filsafat Pendidikan Manusia, Filsafat dan Pendidikan. PT Rajagrafindo Persada. Jakarta

Kaelan dan Zubaidi, Achmad. 2010. Pendidikan Kewarganegaraan. Paradigma. Yogyakarta

2010. Pendidikan Pancasila. Paradigma.

Yogyakarta

Lickona, Thomas. 2013. Pendidikan Karakter Panduan Lengkap Mendidik Siswa
Menjadi Pintar dan Baik. Nusa Media. Bandung

Noor, Rohinah M. 2012. Mengembangkan Karakter Anak Secara Efektif di Sekolah dan di Rumah. Pedagogia. Yogyakarta

Roymon, Dhiki. Pendidikan Karakter Siswa Sesuai Dengan Nilai-Nilai Pancasila di SD Tahunan. Kusumanegara. Yogyakarta.

Samani, Muchlas dan Hariyanto. 2017. Pendidikan Karakter. PT Remaja Rosdakarya. Bandung

Sunggono, Bambang. 2015. Metodologi Penelitian Hukum, Rajagrafindo Persada. Jakarta

Supriono, 2014. Membangun Mahasiswa Berbasis Nilai-Nilai Pancasila Sebagai Revolusi Konflik.

Surajiyo dan Wiyanto, Agus. 2009. Pendidikan Pancasila Di Perguruan Tinggi. Inti Prima Promosindo. Jakarta

Susiatik, Titik. 2013. Pengaruh Pembelajaran PKn Terhadap Pembentukan Karakter Siswa. Semarang

Usiono. 2013. Pancasila Membangun Karakter Bangsa. Hijri Pustaka Utama, Jakarta

Wahyono, Imron. 2017. Implementasi Nilai-Nilai Pancasila Dalam Kegiatan Pembelajaran Di SDN 1 Sekarsuli

Wahyudi. Reaktualisasi Nilai-Nilai Pancasila Dalam Pembangunan Karakter Bangsa Indonesia 